\title{
"I Wanted Them to Be Punished or at Least Ask Us for Forgiveness": Justice Interests of Female Victim-Survivors of Conflict-Related Sexual Violence and Their Experiences with Gacaca
}

Judith Rafferty

James Cook University, Cairns, Australia

Follow this and additional works at: https://digitalcommons.usf.edu/gsp

\section{Recommended Citation}

Rafferty, Judith (2018) "'I Wanted Them to Be Punished or at Least Ask Us for Forgiveness": Justice Interests of Female Victim-Survivors of Conflict-Related Sexual Violence and Their Experiences with Gacaca," Genocide Studies and Prevention: An International Journal: Vol. 12: Iss. 3: 95-118.

DOI:

https://doi.org/10.5038/1911-9933.12.3.1556

Available at: https://digitalcommons.usf.edu/gsp/vol12/iss3/12

This Articles is brought to you for free and open access by the Open Access Journals at Digital Commons @ University of South Florida. It has been accepted for inclusion in Genocide Studies and Prevention: An International Journal by an authorized editor of Digital Commons @ University of South Florida. For more information, please contact digitalcommons@usf.edu. 


\title{
"I Wanted Them to Be Punished or at Least Ask Us for Forgiveness": Justice Interests of Female Victim-Survivors of Conflict-Related Sexual Violence and Their Experiences with Gacaca
}

\author{
Judith Rafferty ${ }^{1}$ \\ James Cook University \\ Cairns, Australia
}

Discussions about the victims of the genocide against the Tutsi ${ }^{2}$ in Rwanda tend to focus on the estimated 500,000 to one million people who were killed between April and July $1994 .{ }^{3}$ Less attention is paid to the number of people who were victims of sexual violence, many of whom have survived to tell their story. This article discusses findings from interviews with 23 Rwandan women who experienced sexual violence during the genocide and had their cases tried in gacaca community courts between 2008 and 2012. The interviews explored the women's needs and motivations to participate in gacaca, as well as their experiences with the process.

Previous studies of gacaca have assessed victims' experiences with the courts. ${ }^{4}$ However, only a few of these studies focus exclusively on female victim-survivors of sexual violence ${ }^{5}$ and are usually limited to gacaca's information gathering phase, while the research discussed in this article focuses on gacaca's trial phase. This research also contributes to a better understanding of what justice means to victim-survivors of conflict-related sexual violence ${ }^{6}$ beyond the case of Rwanda, which, according to Bastick, Grimm and Kunz, is an under-researched topic. ${ }^{7}$ Various scholars have conducted research with victims of human rights abuses to explore their "justice needs." 8 Most of

${ }^{1}$ In this article, the author refers to previous articles that were published under her maiden name, Judith Herrmann.

${ }^{2}$ In its Resolution 2150 in 2014, the UN Security Council made the decision to use the term "genocide against the Tutsi" rather than "the Rwandan genocide." According to TheEastAfrican, the decision came as a response to intensive lobbying by the Rwandan government, who had used the term locally for years, Edmund Kagire, "Genocide against the Tutsi: It's now official," The EastAfrican, February 1, 2014, accessed July 24, 2018, http://www.theeastafrican. co.ke/news/UN-decides-it-is-officially-genocide-against-Tutsi/2558-2169334-x8cirxz/index.html. From here on, "the genocide" is used to refer to the genocide against the Tutsi.

${ }^{3}$ In her analysis of the genocide published by Human Rights Watch, Des Forges concludes that "at least half a million persons were killed" representing a loss of about three quarters of the Tutsi population of Rwanda; Alison Des Forges, Leave None to Tell the Story: Genocide in Rwanda (New York, Washington, London, Brussels: Human Rights Watch, 1999), 15-16. Even though the exact number of people killed during the genocide remains debated, Phil Clark explains that 'most writers estimate the number of Tutsi deaths during the genocide to be in the range of 500,000 to 1 million'; Phil Clark, The Gacaca Courts, Post-Genocide Justice and Reconciliation in Rwanda (Cambridge and New York: Cambridge University Press, 2010), 1; Hollie Nyseth Brehm, et al, "Genocide, Justice, and Rwanda's Gacaca Courts," Journal of Contemporary Criminal Justice 30, no. 3 (2014), 334; Chitra Nagarajan, "An Appraisal of Rwanda's Response to survivors who experienced sexual violence in 1994," Wagadu 10 (2012), 110.

${ }^{4}$ Clark, The Gacaca Courts; Wendy Lambourne, "Transitional Justice after Mass Violence: Reconciling Retributive and Restorative Justice," in Julius Stone: A Study in Influence, ed. Helen Irving, et al., (Sydney: The Federation Press, 2010); Anne-Marie de Brouwer and Etienne Ruvebana, "The Legacy of the Gacaca courts in Rwanda: Survivors' views," International Criminal Law Review 13, no. 5 (2013), accessed July 24, 2018, doi:10.1163/15718123-01305001; Usta Kaitesi, Genocidal Gender and Sexual Violence (Cambridge: Intersentia, 2014); Leslie Haskell, Justice Compromised - The Legacy of Rwanda's Community-Based Gacaca Courts, (USA: Human Rights Watch, 2011); Rakiya Omaar et al., Survivors and PostGenocide Justice in Rwanda (London and Kigali: African Rights and REDRESS, 2008); Lars Waldorf, "Mass Justice for Mass Atrocity: Rethinking Local Justice As Transitional Justice," Temple Law Review 79, no. 1 (Spring 2006).

${ }^{5}$ While it is acknowledged that sexual violence is committed against women, men and children, the term "victimsurvivor" is used to refer to female victim-survivors of sexual violence in this article. The term "victim" is used to refer to any victim of violent crime, including, but not limited to sexual violence.

${ }^{6}$ The United Nations (UN) uses the term 'conflict-related sexual violence' to 'denote sexual violence occurring in a conflict or post-conflict setting that has a direct or indirect causal link with the conflict itself.' see United Nations Security Council, Report of the Secretary-General on the Implementation of Security Council Resolutions 1820 (2008) and 1888 (2009), November 24, 2010, Agenda Item 33 (UN Doc. A/65/592-S/2010/604), 2-3.

${ }^{7}$ Megan Bastick, et al., Sexual Violence in Armed Conflict (Geneva: Geneva Centre for the Democratic Control of Armed Forces, 2007), 165.

${ }^{8}$ Mary P. Koss, "Restoring Rape Survivors," Annals of the New York Academy of Sciences 1087, no. 1 (2006); Judith Lewis Herman, "Justice From the Victim's Perspective," Violence Against Women 11, no. 5 (2005), accesssed October 10, 2017, 
these studies consider victims of violent conflict-related crimes in general, ${ }^{9}$ but only a few focus exclusively on victim-survivors. While some of the needs of survivors of violent crime also apply to victim-survivors ${ }_{1}^{10}$ the latter have some distinct needs that differ from those of victims of other human rights abuses.

This article starts with an overview of the role of sexual violence during the genocide in Rwanda, the functioning of Rwanda's gacaca court system and the handling of sexual violence cases at gacaca. This is followed by an introduction to "justice needs" of survivors of sexual violence and clarification of relevant terminology. The article then analyses two specific justice needs that were discussed during the research interviews: punishment of perpetrators and perpetrators taking responsibility for their actions and the harm caused.

\section{Background}

Sexual violence during the genocide in Rwanda was widespread and extremely brutal. ${ }^{11}$ Various scholars use the term "genocidal sexual violence" to describe the sexual violence committed in Rwanda in $1994,{ }^{12}$ because it was ordered by the leaders of the genocide and specifically targeted Tutsi women, ${ }^{13}$ "contributing to their destruction and to the destruction of the Tutsi group as a whole." 14250,000 - 500,000 women are estimated to having been raped, primarily by members of militia groups, government officials and civilians, who were, in many cases, neighbors or even extended family members of the victim-survivor. ${ }^{15}$ Acts of sexual violence included rape, sexual

doi:10.1177/1077801205274450, http://vaw.sagepub.com/content/11/5/571.abstract; Kathleen Daly, "Reconceptualizing Sexual Vicimization and Justice," in Justice for victims: Perspectives on Rights, Transition and Reconciliation, ed. Inge Vanfraechem, et al., (London and New York: Routledge, 2014); Nicola Henry, "Witness to Rape: The Limits and Potential of International War Crimes Trials for Victims of Wartime Sexual Violence," International Journal of Transitional Justice 3, no. 1 (2009), accessed October 10, 2017, doi:10.1093/ijtj/ijn036, http://ijtj.oxfordjournals.org/ content/3/1/114.abstract.

${ }^{9}$ For example, victims of torture and massacres.

${ }^{10}$ While it is acknowledged that sexual violence is committed against women, men and children, the term survivor of sexual violence from here on refers to women who experienced sexual violence.

${ }^{11}$ Nagarajan, An appraisal of Rwanda's Response, 111; Sarah L. Wells, "Gender, Sexual Violence and Prospects for Justice at the Gacaca Courts in Rwanda," California Law Review E Women's Studies (2005), 182; Kaitesi, Genocidal Gender and Sexual Violence, 77; Binaifer Nowrojee, Shattered Lives - Sexual Violence during the Rwandan Genocide and its Aftermath (USA: Human Rights Watch, 1996), 2; Bastick et al., Sexual Violence in Armed Conflict, 55; Amnesty International, Rwanda: "Marked for Death," Rape Survivors Living with HIVIAIDS in Rwanda, (USA: Amnesty International, 2004), 2; Anne-Marie de Brouwer, et al., The Men Who Killed Me: Rwandan Survivors of Sexual Violence (Vancouver: Douglas \& McIntyre, 2009), 14.

${ }^{12}$ Rebecca L. Haffajee, "Prosecuting Crimes of Rape and Sexual Violence at the ICTR: The Application of Joint Criminal Enterprise Theory," Harvard Journal of Law \& Gender 29 (2006), 201; Nowrojee, Shattered Lives, 1-2; Kaitesi, Genocidal Gender and Sexual Violence, 237. Kaitesi defines genocidal sexual violence as sexual violence committed "with the intent to destroy in part or in whole a national, ethnical, religious or racial group" (taken directly from the Genocide Convention), 15 .

${ }^{13}$ Some Hutu women who were affiliated with Tutsi, for example through marriage, as well as some Tutsi boys and men were also subjected to sexual violence, see Kaitesi, Genocidal Gender and Sexual Violence, 22, 76-77, 80; Sandesh Sivakumaran, "Sexual Violence Against Men in Armed Conflict," European Journal of International Law 18, no. 2 (2007), 257-258; Nowrojee, Shattered Lives, 4; Emily Amick, "Trying international crimes on local lawns: the adjudication of genocide sexual violence crimes in Rwanda's Gacaca courts," Columbia Journal of Gender and Law 20, no. 2 (2011), 8; de Brouwer et al., The Men Who Killed Me, 15.

${ }^{14}$ The Prosecutor versus Jean-Paul Akayesu, Judgement, International Criminal Tribunal for Rwanda, Chamber I, Case No. ICTR-96-4-T, September 2, 1998, 731; René Degni-Ségui, Report on the situation of human rights in Rwanda submitted by Mr. René Degni-Ségui, Special Rapporteur of the Commission on Human Rights, under paragraph 20 of resolution S-3/1 of 25 May 1994, January 29, 1996, Agenda Item 10, (UN Doc. E/CN.4/1996/68), 7 [16]; Bastick et al., Sexual Violence in Armed Conflict, 55; Amnesty International, Rwanda: Marked for Death, 2; Paula Donavan, "Rape and HIV/AIDS in Rwanda," The Lancet 360, no. 1 (2002), 17; Françoise Nduwimana, The Right to Survive Sexual Violence, Women and Hiv/Aids (Montreal: International Centre for Human Rights and Democratic Development, December 2004), 19; Organization for African Unity, Rwanda: The Preventable Genocide (OAU, July 2000), 149 [16.20]; Donatilla Mukamana and Anthony Collins, "Rape Survivors of the Rwandan Genocide," International Journal of Critical Psychology 17 (2006), 144.

${ }^{15}$ Kaitesi, Genocidal Gender and Sexual Violence, 76-77; African Rights, "Broken Bodies, Torn Spirits - Living with Genocide, Rape and HIV/AIDS," (Kigali: African Rights, April 2004), 18-19; Bastick et al., Sexual Violence in Armed Conflict, 55; Amick, Trying international crimes on Local Lawns, 7. 
torture, mutilation, forced incest, sexual slavery and forced "marriage."16 As a result, affected women have been suffering from severe physical and psychological consequences, as well as from social stigma that may attach to survivors of sexual violence. ${ }^{17}$

In the aftermath of the genocide, the United Nations created the International Criminal Tribunal for Rwanda (ICTR) to prosecute the leaders of the genocide, ${ }^{18}$ while the majority of genocide suspects was dealt with by Rwanda's conventional courts and (from 2002) by the gacaca court system. Gacaca comprised approximately 11,000 community courts that were established by the Rwandan government to deal with genocide related crimes. ${ }^{19}$ In 2002, gacaca started as a pilot project, ${ }^{20}$ and in 2005, the courts began operating throughout the country. ${ }^{21}$ On June 18, 2012, one decade after its launch, the gacaca jurisdiction was formally closed, having tried nearly two million cases of around 400,000 genocide suspects during its ten years of existence. ${ }^{22}$

\section{The Gacaca Courts}

The gacaca court system was based on Rwanda's oldest conflict resolution model (traditional gacaca), ${ }^{23}$ and was meant to combine "local conflict resolution traditions with a modern punitive legal system." ${ }^{24}$ Some of the core features of traditional gacaca were continued in modern gacaca. ${ }^{25}$ These features included the location of gacaca proceedings (usually outside in communal spaces), the importance of community participation (local people participated as judges, witnesses, parties and representatives), and links to reconciliation. ${ }^{26}$ Nevertheless, the modern post-genocide proceedings reportedly differed in many ways from the former customary courts. ${ }^{27}$ While traditional gacaca was typically conducted to settle minor civil disputes, ${ }^{28}$ modern gacaca, was established to try genocide suspects, judged by a panel of gacaca judges who were elected by their communities. ${ }^{29}$

${ }^{16}$ Degni-Ségui, Report on the situation of human rights in Rwanda, 13; Kaitesi, Genocidal Gender and Sexual Violence, 76; AVEGA-AGAHOZO, Survey on Violence against Women in Rwanda, (Kigali 1999) (on file with author); Maggie Zraly and Laetitia Nyirazinyoye, "Don't Let the Suffering Make You Fade Away: An Ethnographic Study of Resilience among Survivors of Genocide-Rape in Southern Rwanda," Social Science \& Medicine 70, no. 10 (2010), 1657; Nowrojee, Shattered Lives, 2; Amick, Trying international crimes on local lawns, 8; Kaitesi, Genocidal Gender and Sexual Violence, 22; de Brouwer et al., The Men Who Killed Me, 15.

${ }^{17}$ Nowrojee, Shattered Lives, 2; Lars Waldorf, Transitional Justice and DDR: The Case of Rwanda, (USA: International Center for Transitional Justice, June 2009), 20, accessed October 5, 2018, https://www.ictj.org/sites/default/files/ICTJ-DDRRwanda-CaseStudy-2009-English.pdf.

${ }^{18}$ Mark R Amstutz, "Is Reconciliation Possible After Genocide?: The Case of Rwanda," Journal of Church and State 48, no. 3 (2006), 552.

${ }^{19}$ Republic of Rwanda, Gacaca Courts in Rwanda (Kigali: National Service of Gacaca Courts, 2012); Phil Clark, "The Rules (and Politics) of Engagement: The Gacaca Courts and Post-Genocide Justice, Healing and Reconciliation in Rwanda," in After Genocide: Transitional Justice, Post-Conflict Reconstruction and Reconciliation in Rwanda and Beyond, ed. Phil Clark and Zachary D. Kaufman (New York: Columbia University Press, 2009), 279; The Gacaca Courts, Post-Genocide Justice and Reconciliation, 3; Lambourne, Transitional Justice after Mass Violence, 31, 218; Amstutz, Is Reconciliation Possible After Genocide?, 542.

${ }^{20}$ Allison Corey and Sandra F. Joireman, "Retributive Justice: The gacaca Courts In Rwanda," African Affairs 103 (2004), 83.

${ }^{21}$ Nandor Knust, Strafrecht und Gacaca (Berlin: Duncker \& Humblot, 2013), 30.

${ }^{22}$ Phil Clark, "After Genocide: Democracy in Rwanda, 20 years on," Juncture 20, no. 4 (2014), 309; Republic of Rwanda, Gacaca Courts in Rwanda.

${ }^{23}$ See Republic of Rwanda, Gacaca Courts in Rwanda, 12; Knust, Strafrecht und Gacaca, 20.

${ }^{24}$ Haskell, Justice Compromised; Lambourne, Transitional Justice after Mass Violence, 15.

${ }^{25}$ Ewa Wojkowska, Doing Justice: How Informal Justice Systems can Contribute (Oslo: United Nations Development

Programme, Oslo Governance Centre, 2006), 27; Kaitesi, Genocidal Gender and Sexual Violence, 64.

${ }^{26}$ Clark, The Gacaca Courts, 70; Lambourne, Transitional Justice after Mass Violence, 16-17.

${ }^{27}$ Ibid.

${ }^{28}$ Waldorf, Transitional Justice and DDR.

${ }^{29}$ The gacaca judges of the cell - Rwanda's smallest administrative level - were elected by the Rwandan population in a nationwide election in October 2001, see Paul Christoph Bornkamp, Rwanda's Gacaca Courts (New York: Oxford University Press, 2012), 37. Gacaca judges had to meet certain criteria, including that they must not have participated in the genocide and that they could not hold any official function, see Republic of Rwanda, Organic Law No. 40/2000, January 26, 2001, article 10-1. Once elected, the gacaca judges underwent six weeks of training to learn about the gacaca system, basic principles of the law, group facilitation and conflict resolution. 
Furthermore, modern gacaca represented a hierarchical state-directed initiative, rather than a grassroots approach like traditional gacaca. ${ }^{30}$ Finally, modern gacaca applied codified law, documented in writing, rather than verbally transmitted, customary law. ${ }^{31}$

The Rwandan government was committed to "end the culture of impunity" and hold accountable everyone suspected of having contributed to the genocide. ${ }^{32}$ Penalties for offenses were determined according to the categorization and sentencing scheme of the gacaca law. ${ }^{33}$ Choosing gacaca to process the majority of genocide suspects, the Rwandan government had to make a number of compromises, especially regarding the rights of the accused, qualifications of gacaca staff and applicable legal standards. ${ }^{34}$ It was, however, believed that the transparency of the process and the participation of the community would legitimize the process and protect the rights of all participants. ${ }^{35}$

Gacaca functioned as system of three stages: information gathering, classification of genocide suspects and trial of suspects. During the information gathering stage, gacaca judges (called inyangamugayo, which means "person of integrity") and their local communities met once a week to collect information about victims, perpetrators and crimes committed during the genocide. ${ }^{36}$ In the second stage, based on the previously collected information, the judges put together case files of genocide suspects and categorized their crimes according to their severity. ${ }^{37}$ Based on a complex categorization system from Rwanda's genocide law of $1996,{ }^{38}$ gacaca law classified alleged planners and organizers of the genocide, as well as those accused of rape and sexual torture as category 1 suspects. ${ }^{39}$ People, who were accused of having been involved in killings and other violent acts against people, both with and without the intent to kill, were classified as category $2 .^{40}$ Category 3 comprised acts committed against property..$^{41}$ During gacaca's third stage, gacaca judges heard and judged the cases that had been allocated to their gacaca jurisdiction. ${ }^{42}$

The Rwandan government introduced gacaca with the aim to end impunity, speed up genocide trials, ${ }^{43}$ and promote truth, justice and reconciliation. ${ }^{44}$ Truth, justice and reconciliation were meant to

${ }^{30}$ Clark, The Gacaca Courts, 71.

${ }^{31}$ Ibid.; Wojkowska, Doing Justice.

${ }^{32}$ William A. Schabas, "Genocide Trials and gacaca Courts," Journal of International Criminal Justice 3 (2005), 4; Judith Herrmann, "A Critical Analysis of the Transitional Justice Measures Incorporated by Rwandan gacaca and their Effectiveness," James Cook University Law Review 19 (2012), 95.

${ }^{33}$ Republic of Rwanda, Gacaca Courts in Rwanda.

${ }^{34}$ Haskell, Justice Compromised, 112.

${ }^{35}$ Ibid.

${ }^{36}$ Clark, The Gacaca Courts, 76.

${ }^{37}$ The categorization of genocide crimes was changed several times from the start of gacaca to its last year of operation. The categorisation listed in this article is based on the final amendment as per Republic of Rwanda, Organic Law No. 10/2007 of March 1, 2007 outlined in Republic of Rwanda, Gacaca Courts in Rwanda, 98-99.

${ }^{38}$ Republic of Rwanda, Organic Law No. 08/96, August 30, 1996; Republic of Rwanda, Gacaca Courts in Rwanda, 42-44.

${ }^{39}$ Republic of Rwanda, Gacaca Courts in Rwanda, 98-99. In this article, the term sexual violence includes sexual torture and rape.

${ }^{40}$ Ibid.; the gacaca law of 2001 used four categories of genocide crimes. In 2004, category 2 and 3 were merged to become category 2, while the early category 4 became category 3, see ibid., 66-75.

${ }^{41}$ Ibid., 98-99. Kaitesi explains that property damage traditionally would not qualify as genocide. However, in the context of the genocide in Rwanda, destruction of property was part of the overall plan to destroy the Tutsi as a group, and was thus included in the crimes punishable as genocide-related offenses, Kaitesi, Genocidal Gender and Sexual Violence, 69.

${ }^{42}$ Crimes of category 3 were tried by gacaca courts of the cell, while category 2 crimes were allocated to gacaca courts at the sector level, see Republic of Rwanda, Organic Law No. 16/2004, June 19, 2004, articles 34, 42. Category 1 crimes were tried by a number of different Rwandan justice initiatives. Initially, category 1 crimes were allocated for trial to Rwanda's specialised chambers. In 2004, these specialised chambers were disestablished and category 1 crimes were transferred to Rwanda's ordinary courts, until an amendment to the law in 2008 assigned competency to gacaca courts to try the majority of the remaining category 1 cases, see Republic of Rwanda, Organic Law No. 13/2008, May 19, 2008, article 1.

${ }^{43}$ After the genocide, approximately 120,000 suspects "were arrested and provisionally detained for the crime of Genocide and other crimes against humanity," see Republic of Rwanda, Gacaca Courts in Rwanda, 14.

${ }^{44}$ Republic of Rwanda, Organic Law No. 40/2000, 2; Clark, The Gacaca Courts, 3. The following specific goals were articulated for gacaca: to reveal the truth about Genocide; to speed up the cases of Genocide and other crimes against 
be supported by a number of measures, including gacaca's participatory and communal structure. ${ }^{45}$ Another important tool to foster reconciliation were special procedures for confessions, guilty pleas, repentance and apologies specified in gacaca law. ${ }^{46}$ These procedures allowed for reduced sentences for the majority of those who pleaded guilty. ${ }^{47}$ Opinions of survivors and scholars differ in how far the guilty plea procedures contributed to reconciliation. Amstutz explains that many survivors have expressed willingness to forgive perpetrators who confessed and apologized. ${ }^{48}$ Other survivors have reportedly criticized that perpetrators did not show genuine remorse but only made use of the guilty plea rule to reduce their sentence. ${ }^{49}$

While gacaca included some restorative elements aimed at fostering reconciliation, ${ }^{50}$ various scholars argue that the retributive nature of the courts prevailed by far and may have hampered reconciliation. ${ }^{51}$ Another obstacle affecting the reconciliation process was the lack of compensation for personal injury of genocide. Overall, gacaca had only limited provisions in terms of reparations. ${ }^{52}$ These provisions mainly applied to lower level crimes and consisted of symbolic reparations and compensation for loss of property, including monetary compensation and unpaid labor. ${ }^{53}$ Gacaca did not enable reparations for victim-survivors, which has frequently been criticized by a range of audiences, including genocide survivors, scholars and aid organizations. ${ }^{54}$

\section{Sexual Violence in Gacaca}

Until 2008, rape and sexual torture committed during the genocide were not tried by gacaca courts, but were dealt with by Rwanda's national courts, since they were classified as category 1 crimes. ${ }^{55}$

humanity; to eradicate the culture of impunity; to strengthen unity and reconciliation among Rwandans; to prove the Rwandans' capacity to solve their own problems, Republic of Rwanda, Gacaca Courts in Rwanda, 33.

${ }^{45}$ Herrmann, A Critical Analysis of the Transitional Justice Measures, 94-96; Wendy Lambourne and Lydia Wanja Gitau, "Psychosocial interventions, peacebuilding and development in Rwanda," Journal of Peacebuilding and Development 8 , no. 3 (2013), 28; Lambourne, Transitional Justice after Mass Violence, 15; Sarah L. Wells, "Gender, Sexual Violence and Prospects for Justice at the Gacaca Courts in Rwanda," California Law Review \& Women's Studies 167 (2005), 26; Clark highlights gacaca's uniqueness as a justice institution due to "its mass involvement of the population that experienced mass conflict firsthand," Clark, The Gacaca Courts, 3.

${ }^{46}$ Republic of Rwanda, Organic Law No. 40/2000, article 54. These procedures had been adopted and slightly amended from Republic of Rwanda, Organic Law No. 08/96, articles 4-9. For confessions to be considered by gacaca, defendants had to 1) give a detailed description of the confessed crime, 2) disclose any accomplices and 3) apologise for the offense(s) committed. Gacaca prescribed that apologies had to "be made publicly to the victims in case they ... [were] still alive and to the Rwandan Society," Republic of Rwanda, Organic Law No. 16/2004, article 54. Gacaca law provided further incentives for early confessions and allowed for additional reduction of the penalty when confessions were made before a person was put on the list of those accused of genocide, see Republic of Rwanda, Gacaca Courts in Rwanda.

${ }^{47}$ Until a change to the law in 2001, persons accused of category 1 crimes, which included sexual violence, could not benefit from reduced sentences through confessions. Pleading guilty to a category 1 crime before 2001 resulted in the death penalty (even though the death penalty was not executed after 1998 and was abolished in 2007; see Brehm, Uggen, and Gasanabo, Genocide, Justice, and Rwanda's Gacaca Courts, 348). Therefore, there was initially little incentive for anyone to confess to sexual violence. Guilty plea rules were changed as part of the Organic Law of 2001, extending reduced sentences for confession of category 1 crimes, see Kaitesi, Genocidal Gender and Sexual Violence, 63, 202-203; Republic of Rwanda, Gacaca Courts in Rwanda, 19-23, 42.

${ }^{48}$ Amstutz, Is Reconciliation Possible After Genocide?, 559.

${ }^{49}$ Prisca Uwigabye, "Gacaca and the Treatment of Sexual Offenses," in Trials and Tribulations of International Prosecution, ed. Henry F. Carey and Stacey M. Mitchell (Lanham: Lexington Books, 2013), 276; Haskell, Justice Compromised.

${ }^{50}$ Herrmann, A Critical Analysis of the Transitional Justice Measures, 6.

${ }^{51}$ Schabas, Genocide Trials and gacaca Courts, 3-4; Lambourne questions the reconciliatory value of gacaca due to its 'overemphasis on retributive justice'; Lambourne, Transitional Justice after Mass Violence, 20. Uwigabye, who conducted interviews with Rwandan women survivors of sexual violence, comments that "restitution was not given the priority it needed to promote reconciliation"; Uwigabye, Gacaca and the Treatment of Sexual Offenses, 276-277.

${ }^{52}$ Herrmann, A Critical Analysis of the Transitional Justice Measures, 96-97, 107.

${ }^{53}$ Waldorf, Transitional Justice and DDR, 17-18.

${ }^{54}$ Republic of Rwanda, Gacaca Courts in Rwanda, 185. Herrmann, A Critical Analysis of the Transitional Justice Measures, 96-97, 107. Uwigabye, Gacaca and the Treatment of Sexual Offenses, 277.

${ }^{55}$ Initially, category 1 crimes were tried at Rwanda's national courts, until an amendment to the law in 2008 assigned competency to gacaca courts to try the majority of the remaining category 1 cases, see Republic of Rwanda, Organic Law No. 13/2008, article 1. 
However, during the information gathering stage of gacaca, $^{56}$ the community courts were functioning as the prosecution and were collecting information about perpetrators, victims and crimes committed during the genocide. ${ }^{57}$ This information included evidence relating to sexual violence cases that would later be referred to in Rwanda's national courts. ${ }^{58}$ During the information gathering stage of gacaca's pilot phase, affected women and other community members, including perpetrators, could publicly raise cases of sexual violence at gacaca hearings. According to Kaitesi, "a great deal was spoken about sexual torture" during these first years of gacaca. ${ }^{59}$ All Rwandans were by law required to participate in gacaca, $^{60}$ which may have prompted some affected women and other community members to talk about sexual violence. Nevertheless, while an estimated 250,000 to 500,000 women were raped during the genocide, less than 7000 cases of sexual violence have reportedly been brought to the Rwandan justice system. ${ }^{61}$ These figures demonstrate that most survivors of sexual violence did not raise their case during gacaca. Several reasons are likely to have contributed to the silence of many survivors of sexual violence, including shame, ${ }^{62}$ as well as fear of re-traumatization, ${ }^{63}$ stigma and marginalization, ${ }^{64}$ or being unable or unwilling to identify the perpetrator. ${ }^{65}$

In 2008, amendments were made to gacaca law, transferring competency from the national courts to gacaca to try cases of sexual violence. ${ }^{66}$ According to Kaitesi and Haveman, "about 7000 cases of rape and sexual torture were tried by 17,000 judges ... in 1,900 gacaca tribunals"

${ }^{56}$ Information about the genocide was collected at gacaca between the $18^{\text {th }}$ June 2002 (when the first gacaca courts of the pilot project were launched) and the $30^{\text {th }}$ June 2006; see Republic of Rwanda, Gacaca Courts in Rwanda, 53, 87.

${ }^{57}$ Republic of Rwanda, Organic Law No. 40/2000, article 34.

${ }^{58}$ Ibid.; Kaitesi, Genocidal Gender and Sexual Violence, 209.

${ }^{59}$ Kaitesi, Genocidal Gender and Sexual Violence, 208.

${ }^{60}$ Republic of Rwanda, Organic Law No. 16/2004, article 29.

${ }^{61}$ According to Kaitesi, about 7000 cases of sexual violence were tried at gacaca; see Kaitesi, Genocidal Gender and Sexual Violence, 385. Amick reports more specifically that 6608 cases of rape and sexual torture were transferred to gacaca jurisdiction in 2008; Amick, Trying International Crimes on Local Lawns, 3, citing Republic of Rwanda, Gacaca Courts Process: Implementation and Achievement (The National Service of Gacaca Courts, 2008). Before the referral of these 6608 cases to gacaca in 2008, sexual violence cases were dealt with by gacaca's ordinary courts. HRW reports that 32 cases including charges of sexual violence were heard before the ordinary courts between 1996 and 2003, see Human Rights Watch, Struggling to Survive: Barriers to Justice for Rape Victims in Rwanda, (New York: Women's Rights Division, 2004), 18. This is also supported by Amnesty International who refer to an interview with the women's rights organization Haguruka in March 2004, reporting that "significantly less than 100 women" had their cases of sexual violence tried by an ordinary court by 2004; Amnesty International, Rwanda: "Marked for Death,"16.

${ }^{62}$ Kaitesi, Genocidal Gender and Sexual Violence, 210; Usta Kaitesi and Roelof Haveman, "Prosecution of Genocidal Rape and Sexual Torture before the Gacaca Tribunals in Rwanda," in Victimological Approaches to International Crimes: Africa, ed. Rianne Letschert, et al. (Cambridge, Antwerp, Portland: Intersentia, 2011), 399; Uwigabye, Gacaca and the Treatment of Sexual Offenses, 275.

${ }^{63}$ Many of those women whose cases were discussed publicly at a gacaca hearing suffered episodes of severe trauma, see Karen Brounéus, "Truth-Telling as Talking Cure? Insecurity and Retraumatization in the Rwandan Gacaca Courts," Security Dialogue 39, no. 1 (2008). See also Wells, Gender, Sexual Violence and Prospects for Justice at the Gacaca Courts in Rwanda. In the course of gacaca, the Rwandan government recognised the (re-) traumatisation potential of gacaca and made various changes to the law to better protect women's confidentiality and support them during the process.

${ }^{64}$ See Nowrojee, Shattered Lives, 3; AVEGA-AGAHOZO, Survey on Violence against Women in Rwanda, 22; Waldorf, Transitional Justice and DDR, 20. Amnesty International explains that derogatory attitudes of both men and women towards survivors of rape are deeply entrenched in Rwanda and that Rwandan women who were exposed as survivors of rape were isolated from their communities, experiencing humiliations by men, women and children, including their own families, Amnesty International, Rwanda: "Marked for Death," 5. See also Christopher W. Mullins, "'We Are Going to Rape You and Taste Tutsi Women': Rape during the 1994 Rwandan Genocide," The British Journal of Criminology 49, no. 6 (2009), 725.

${ }^{65}$ Many women were raped by strangers and the women could not report them at gacaca, since the perpetrators' identities were unknown.

${ }^{66}$ Republic of Rwanda, Organic Law No. 13/2008, article 1. More specifically, the changes made to gacaca law assigned competency to gacaca to try most remaining category 1 cases, of which the majority were cases of rape and sexual torture. 9352 category 1 cases plus 1265 additional cases from the Ordinary and Military Courts were transferred to gacaca in 2008, see Republic of Rwanda, Gacaca Courts in Rwanda, 208. According to Amick, these cases included 6608 cases of rape and sexual torture; Amick, Trying international crimes on local lawns, 3, citing Republic of Rwanda, Gacaca Courts Process: Implementation and Achievement (The National Service of Gacaca Courts, 2008). 
between mid-2008 and mid-2009. ${ }^{67}$ As opposed to the usually public gacaca proceedings, all trials that included charges of sexual violence were held in camera.$^{68}$ An in camera trial required the participation of five specially trained gacaca judges, ${ }^{69}$ the victim-survivor and the defendant(s) (in cases where defendants had fled the country, trials could be held in absentia). ${ }^{70}$ Furthermore, the attendance of gacaca court supervisors, security officers and a trauma counselor to accompany the victim-survivor was permitted..$^{71}$ Outside observers of gacaca trials dealing with sexual violence were not allowed and gacaca documents on sexual violence are currently not publicly available. ${ }^{72}$ Therefore, "little first-hand data exists on how [these] trials were handled."73 Since gacaca judges and trauma counselors are bound by confidentiality, ${ }^{74}$ only the victim-survivors themselves can currently provide information on what happened during these trials. Therefore, the research discussed in this article provides unique information on the gacaca process and judgments reached.

\section{Justice Needs of Survivors of Sexual Violence}

Research shows that victims who have suffered gross human rights abuses need to experience a sense of justice. ${ }^{75}$ If victims do not feel that justice has been achieved, they may suffer a range of potential repercussions, including self or other harm, depression and aggression. ${ }^{76}$ That said, achieving justice for victims is a great challenge. Bastick et al. point out that justice is "simultaneously personal to each individual survivor, an issue for entire communities, and has national and international dimensions and there are tensions inherent in locating justice in these different spaces." 77 Van der Merwe stipulates that evaluating justice for victims should go beyond the question of whether a perpetrator has been "sufficiently" punished, but should also consider other elements such as vindication of the victim, information about why and how the victim became victimized, as well as opportunities for victims to regain control, power and a sense of meaning in society ${ }^{78}$ Researchers such as Lambourne and Mani also propose different types of justice that go beyond legal justice or punishment and that are relevant for meeting the needs of victims of genocide and other mass violence. $^{79}$

${ }^{67}$ Kaitesi and Haveman, Prosecution of Genocidal Rape, 385.

${ }^{68}$ Republic of Rwanda, Organic Law No. 13/2008, article 6; Kaitesi, Genocidal Gender and Sexual Violence, 232. The regulations concerning the in camera trials were established in response to complaints and episodes of trauma experienced by women during public gacaca proceedings, see ibid., 7, 218, 232.

${ }^{69}$ This training included both legal and psychological aspects focusing on prosecuting cases of rape and sexual and handling traumatic reactions, Kaitesi and Haveman, Prosecution of Genocidal Rape, 398-406.

${ }^{70}$ Kaitesi, Genocidal Gender and Sexual Violence, 218, 232.

${ }^{71}$ Republic of Rwanda, Organic Law No. 13/2008, article 6; Kaitesi, Genocidal Gender and Sexual Violence, 218, 232.

72 The National Commission for the Fight Against Genocide (CNLG) will currently "not give to anyone Gacaca documents on sexual violence during the genocide"; email correspondence with the General of the Research and Documentation Center on Genocide within the National Commission for the Fight Against Genocide (CNLG), Jean-Damascène Gasanabo, on October 4, 2015.

${ }^{73}$ Haskell, Justice Compromised, 112.

${ }^{74}$ Gacaca judges were by law prohibited to reveal information about a sexual violence gacaca hearing, Republic of Rwanda, Organic Law No. 13/2008, article 5.

${ }^{75}$ Hugo Van der Merwe, "Delivering Justice during Transition: Reserach Challenges," in Assessing the impact of transitional justice: challenges for empirical research, ed. Hugo Van der Merwe, et al. (Washington, DC: United States Institute of Peace Press, 2009), 123; Bastick et al, Sexual Violence in Armed Conflict, 165; Rama Mani, "Integral Justice for Victims," in Justice for victims, ed. Inge Vanfraechem, Antony Pemberton, and Felix Mukwiza Ndahinda (London and New York: Routledge, 2016), 183; Wendy Lambourne, "Transformative justice, reconciliation and peacebuilding," in Transitional Justice Theories ed. Susanne Buckley-Zistel, et al. (London: Routledge,, 2014), 23-32; Jo-Anne Wemmers, "Victims' Need for Justice. Individual versus Collective Justice," in Victimological Approaches to International Crimes: Africa, ed. Rianne Letschert, et al. (Cambridge, Antwerp, and Portland: Intersentia, 2011), 145.

${ }^{76}$ Mani, Integral Justice for Victims, 183.

${ }^{77}$ Bastick et al, Sexual Violence in Armed Conflict, 165.

${ }^{78}$ Van der Merwe, Delivering Justice during Transition, 123.

${ }^{79}$ Rama Mani, Beyond Retribution: Seeking Justice in the Shadows of War (Cambridge and Malden: Polity Press and Blackwell Publishers Inc, 2002); Rama Mani, Integral Justice for Victims. Based on interviews with survivors of genocide and other mass violence, Lambourne found that socio-economic justice, political justice, truth and acknowledgement were also important in addition to punishment or legal justice; Lambourne, Transformative Justice, Reconciliation and Peacebuilding. 
Studies undertaken with victim-survivors in various contexts have identified several justice interests that are specific to survivors of sexual violence. These justice interests include voice (tell their story and be heard), participation, validation, vindication, accountability of perpetrators (which includes perpetrators taking responsibility) and punishment. ${ }^{80}$ At the same time, Daly argues that justice interests of survivors of sexual violence is "an emergent and untested construct," requiring further research. ${ }^{81}$ This article adds evidence to further develop the construct by analyzing the needs, motivations and experiences of 23 Rwandan women who participated in gacaca. The article focuses on two specific justice interests that emerged during the interviews: punishment and perpetrators taking responsibility. Both terms are discussed below to clarify their meaning in this article.

\section{Punishment}

Research indicates that punishment is important for some victim-survivors. For example, in Sharratt's study with victim-survivors who testified before the International Criminal Tribunal for the Former Yugoslavia (ICTY) and the War Crimes Court (WCC) in Bosnia and Herzegovina, ${ }^{82}$ over $75 \%$ of the women claimed that the main reason for their participation was "because rape and sexual assault is a crime and needs to be punished." 83 In contrast, Nowrojee, who conducted research with victim-survivors who participated at the ICTR, comments that "punishment... [was] astonishingly the least articulate reasons for why Rwandan women wanted and valued ICTR prosecutions of rape." ${ }^{84}$

From a legal point of view, punishment may be imposed for various reasons, including retribution, rehabilitation, deterrence and incapacitation. ${ }^{85}$ Punishment, from the point of view of a victim-survivor, may be valued for similar and /or other reasons, depending on the survivor's personal situation and context. ${ }^{86}$

A retributive approach to punishment assumes that the perpetrator "owes a debt" and deserves to be punished. ${ }^{87}$ As part of a retributive approach, guilt is "established and appropriate consequences (punishment) determined." 88 As a general principle, "appropriate consequences" requires punishment to be "proportionate to the amount of harm done." 89 Research shows that in cases where victim-survivors viewed punishment as too light, the punishment was perceived as a minimization of the victim-survivors' suffering. ${ }^{90}$ Therefore, from a victim-survivor's perspective,

${ }^{80}$ Daly, Reconceptualizing Sexual Vicimization and Justice, 388; Koss, Restoring Rape Survivors, 209; Herman, Justice From the Victim's Perspective; Henry, Witness to Rape; Sara Sharratt, Gender, Shame and Sexual Violence (Farnham and Burlington: ASHGATE, 2011); Binaifer Nowrojee, "'Your Justice Is Too Slow' Will the International Criminal Tribunal for Rwanda Fail Rwanda's Rape Victims?," in Gendered Peace, ed. Donna Pankhurst (New York and Oxon: Routlege \& UNRISD, 2008); Uwigabye, Gacaca and the Treatment of Sexual Offenses.

${ }^{81}$ Daly, Reconceptualizing Sexual Vicimization and Justice, 389.

${ }^{82}$ While this article focuses on Rwandan victim-survivors, the author considered studies with victim-survivors in other contexts, including at the ICTY, for purpose of analyzing victim-survivors' justice interests. Like the ICTR, the ICTY also dealt with conflict-related sexual violence. Both tribunals contributed significantly to the recognition of sexual violence and rape in the categories war crimes, torture, crimes against humanity and genocide.

${ }^{83}$ Sharratt, Gender, Shame and Sexual Violence, 114.

${ }^{84}$ Nowrojee, Your Justice Is Too Slow, 111. Similarly, research with survivors of sexual violence in the US revealed that "the concept of punishment as a so-called debt to society found little support among ... [the women interviewed for the research]", Herman, Justice From the Victim's Perspective, 590.

${ }^{85}$ Roger Matthews, "Punitiveness," in The SAGE dictionary of criminology, ed. Eugene McLaughlin and John Muncie (London and Thousand Oaks: SAGE Publications Limited, 2013), 352.

${ }^{86}$ Hugo Van der Merwe, "What Survivors Say about Justice: An Analysis of the TRC Victim Hearings," in Truth and Reconciliation in South Africa: Did the TRC Deliver?, ed. Audrey R. Chapman and Hugo Van der Merwe (Philadelphia: Pennsylvania Press 2008), 44.

${ }^{87}$ Maggie Sumner, "Retribution," in The SAGE dictionary of criminology, ed. Eugene McLaughlin and John Muncie (London and Thousand Oaks: SAGE Publications Limited, 2013), 386; Van der Merwe, What Survivors Say about Justice; Matthews, Punitiveness, 31.

${ }^{88}$ Van der Merwe, What Survivors Say about Justice, 31.

${ }^{89}$ Sumner, Retribution, 386-387.

${ }^{90}$ Henry, Witness to Rape, 131. 
punishment may serve as a personal means of validation of the harm experienced, which may or may not be commensurate with the legal measure of retribution.

A victim-survivor's demand for punishment may be driven by underlying interests and needs associated with specific types of punishment. ${ }^{11}$ For example, various studies have shown that punishment of the perpetrator in the form of imprisonment was linked to needs for safety of self and others, since some survivors feared that their perpetrator was likely to re-offend in the future. ${ }^{92}$

Perpetrators Taking Responsibility

Various studies have identified that it is important for victims that their perpetrators take active responsibility for their actions and the harm caused..$^{93}$ Taking active responsibility can be demonstrated by expressions of sincere regret and remorse, for example by way of an apology. ${ }^{94}$ Van der Merwe suggests that taking responsibility may also involve perpetrators paying reparations to the victim. ${ }^{95}$ Perpetrators may also assume responsibility by giving accounts for their actions, ${ }^{96}$ which includes an explanation of what the perpetrator did and why he/she did it. ${ }^{97}$ Perpetrators may assume responsibility for their actions in front of a court or other official instance, ${ }^{98}$ or it may involve accountability to the survivor and/or their communities. ${ }^{99}$

Some studies involving victim-survivors show that perpetrators taking responsibility is an important justice interest of at least some affected victim-survivors. ${ }^{100}$ For example, in Herman's study, some victim-survivors "expressed a fervent wish for a sincere apology and believed that this would be the most meaningful restitution the offender could give." ${ }^{101}$ At the same time, the topic of perpetrators taking responsibility appears to be less discussed than other justice interests in relevant literature.

\section{Methodology}

The research discussed in this article involved semi-structured interviews with 23 Rwandan women who met the following criteria: 1) The woman had experienced sexual violence during the genocide and 2) the woman had her case tried by a gacaca court. ${ }^{102}$ All women had their cases tried

\footnotetext{
${ }^{91}$ Herman, Justice From the Victim's Perspective.

${ }^{92}$ de Brouwer and Ruvebana, The Legacy of the Gacaca Courts in Rwanda: Survivors' Views, 951; Ibid., 595. In her study Herman revealed that most women valued alternative measures of punishment (other than imprisonment), driven by a desire for financial restitution, the survivor's safety and vindication. Herman highlights in her analysis that the majority of survivors interviewed had not raised their case to seek retribution, but to be vindicated, ibid., 590 .

${ }^{93}$ Van der Merwe, What Survivors Say about Justice, 31; Daly, Reconceptualizing Sexual Vicimization and Justice, 388; Koss, Restoring Rape Survivors. Several scholars, including Van der Merwe and Daly, use the umbrella term (offender) accountability to refer to perpetrators taking active responsibility. Other scholars have used other terms to refer to what is summarised under perpetrators taking responsibility in this article. For example, Lambourne uses the term acknowledgement; see Wendy Lambourne and Vivianna Rodriguez Carreon, "Engendering Transitional Justice: a Transformative Approach to Building Peace and Attaining Human Rights for Women," Human Rights Review (2015), 27-28.

${ }^{94}$ Daly, Reconceptualizing Sexual Vicimization and Justice, 388.

${ }^{95}$ Van der Merwe, What Survivors Say about Justice, 31.

${ }^{96}$ Daly, Reconceptualizing sexual vicimization and justice, 388.

${ }^{97}$ Van der Merwe, What Survivors Say about Justice, 31, 33. Giving account for the motives behind an offense was a dominant request made by the survivors regarding accountability in van der Merwe's research, 33.

${ }^{98}$ Termed "official accountability," ibid., 33.

${ }^{99}$ Ibid., 33.

${ }^{100}$ Herman, Justice From the Victim's Perspective, 586; Koss, Restoring Rape Survivors, 209; Kathleen Daly and Sarah CurtisFawley, "Justice for Victims of Sexual Assault: Court or Conference?" in Gender and Crime: Patterns of Victimization and Offending, eds. Karen Heimer and Candace Kruttschnitt (New York: New York University Press, 2006), 240-241, 244-246; Shivon Byamukama, "Justice in the Aftermath of the 1994 Rwanda Genocide: A Study of Gacaca Courts" (Glasgow: Glasgow Caledonian University, 2008), 259-260.

${ }^{101}$ Herman, Justice From the Victim's Perspective, 586.

${ }^{102}$ Two Rwandan professionals who worked with genocide survivors assisted in identifying women who met the selection criteria. The 23 women who participated in the research were recruited through the following two methods: 1) The author's invitation to participate in the research was passed on to potential participants by the professionals who worked with these women. 2) Passive snowball recruitment was used: women who had been personally invited by
} 
in urban and rural locations in two different areas of Rwanda. ${ }^{103}$ The women were aged between 42 and 68; only one had a monthly income.

The methodology of this research was informed by phenomenological and feminist approaches to research, which assisted in responding to challenges associated with qualitative research involving vulnerable groups. ${ }^{104}$ Interview questions aimed at eliciting the women's motivations, expectations and needs when raising their case at gacaca and the impact of participating in the process from the women's point of view. The women were also encouraged to describe in detail what happened during and after their gacaca trial. All interviews were conducted by the author of this article, assisted by a Kinyarwanda-English interpreter, since the author did not speak Kinyarwanda. ${ }^{105}$ The Kinyarwanda responses were later transcribed and translated by a Kinyarwanda-English translator for the purpose of this analysis. ${ }^{106}$

\section{Themes}

The women's motivations to raise their case at gacaca were diverse, including hopes for punishment, perpetrators taking responsibility (particularly by way of apology / asking for forgiveness), truth and reparations, including medical and financial support. The following discussion focuses on the women's views on punishment and perpetrators taking responsibility. ${ }^{107}$

\section{Punishment}

Punishment was a topic discussed by all 23 women at some stage during the interview. About half of the women spoke about punishment when asked what they had hoped and/or expected to achieve by raising their case at gacaca. All but one woman reported that at least one of their perpetrators (many women had raised cases that involved multiple perpetrators) ${ }^{108}$ was found guilty and punished, predominantly with life imprisonment. ${ }^{109}$ When sexual violence cases were tried at gacaca, life imprisonment (with special provisions) constituted the maximum penalty according to gacaca law. ${ }^{110}$ Some perpetrators received reduced sentences of 25-30 years since they

the professionals were encouraged to pass on the information about the study to other women who they knew met the selection criteria.

${ }^{103}$ Further details regarding geographical location of interviews are withheld for security and confidentiality reasons.

${ }^{104}$ The research methodology used for this research is outlined in Judith Herrmann, "Experiences, challenges, and lessons learned - interviewing Rwandan survivors of sexual violence," Griffith Journal of Law \& Human Dignity 5, no. 1 (2017). The article explains in detail how the research met Rwandan and international standards, how interview participants were identified and invited, how consent was gained, how the interviews were conducted, how rapport was established and how other ethical and practical challenges were addressed.

${ }^{105}$ During the interviews, the author asked all interview questions in English. The questions were then translated into Kinyarwanda by the interpreter. All interview participants responded in Kinyarwanda, which was then translated into English by the interpreter.

${ }^{106}$ Challenges associated with researching in another language and how they were addressed in this research are discussed in Herrmann, Experiences, Challenges, and Lessons Learned.

${ }^{107}$ Further publications are planned by the author to discuss other elements of victim-survivors' justice interests that emerged during the research.

${ }^{108}$ For example, informant M16 had raised her case against 30 individuals; interview conducted with M16, December 29, 2015.

${ }^{109}$ Sixteen women spoke about life sentences imposed on their perpetrator(s). Apart from that, one perpetrator was reportedly sentenced to 20 years, one to 27 years, one to 28 years and two to 30 years. One informant mentioned that her perpetrator was first sentenced to life imprisonment but was then acquitted in an appeals process.

${ }^{110}$ In the very early stages of gacaca, the maximum penalty was the death penalty. However, according to Amnesty International, 'the last death sentences were imposed in 2003', while 'the [first and] last executions took place in 1998, see Amnesty International, "Rwanda: Abolition of the Death Penalty," (public statement July 27, 2007). Brehm, Uggen, and Gasanabo report that after 1998, executions reportedly stopped, and the death penalty was officially abolished in 2007, Brehm et al, Genocide, Justice, and Rwanda's Gacaca Courts, 348. As per Republic of Rwanda, Organic Law 31/2007 of July 25, 2007, the death penalty was substituted by life imprisonment or life imprisonment with special provisions. These special provisions include that 1) "a convicted person is not entitled to any king of mercy, conditional release or rehabilitation, unless he/she has served at least twenty (20) years of imprisonment", and 2) that "a convicted person is kept in isolation." About half of the women interviewed for this research went through appeals processes, some of them initiated by the perpetrator, some initiated by the women themselves since they had not been satisfied with the outcome of their first trial. Many cases had initially ended with the acquittal of the perpetrator/s and only the appeals 
had pleaded guilty during the trial. ${ }^{111}$ M22. ${ }^{112}$

Many women expressed positive feelings about their perpetrators being punished, such as

M22: I was happy about [the sentence, which was life in prison].

Interpreter (I): Why were you happy about it?

M22: Whenever someone has committed a crime against you and they get punished for it, it makes you happy. ${ }^{113}$

M22 had raised charges of sexual violence against seven men. All men had denied these charges but had been found guilty by the gacaca judges and sentenced to life imprisonment in solitary confinement. M22 had raised her case in gacaca, because "she wanted the criminals to pay" for what they had done.

It appeared that for some women, the punishment of the perpetrator was something that stood out for them as a positive experience at gacaca. One woman (M7) had been raped and assaulted by two men who both received a life sentence. While M7 had submitted her case at gacaca with the main objective to expose the truth about what had happened during the genocide, she valued the punishment of her perpetrators above all. When asked to reflect on gacaca and describe any positive experience, M7 explained: "I was happy about the fact that the people who hurt me were found and punished. That is what made me happy."114

Some of the women alluded that they were satisfied with the penalty handed out by the gacaca judges, such as M21. M21 had been raped by 20 men. While some of them had fled the country, eight suspects were tried at gacaca. All defendants denied the charges but were sentenced to life imprisonment with special provisions. M21 had raised her case since she "wanted the people who had killed our family members and raped us to be punished". When asked how she felt about the life sentence, M21 explained:

I was happy with [the sentence of life imprisonment] because that is the biggest sentence you can get in Rwanda. They have abolished the death penalty, so I had to be okay with that sentence. ${ }^{115}$

For M21, as for some other women, it appeared to be important that her perpetrators had received the maximum penalty according to Rwandan law.

While most women considered the prison sentences that their perpetrators had received as appropriate, one woman (M20) commented that even the highest possible penalty was inadequate to capture the harm that she had experienced:

I feel like they were given a serious sentence [life in prison] even though it does not match the fact that they killed my family and did horrible things to me. There is not a sentence big enough to match what they did to me. ${ }^{116}$

trial resulted in a guilty verdict.

${ }^{111}$ As per the Organic Law of 2007, defendants found guilty of rape and sexual torture were punished with life imprisonment if they refused to confess or if their guilty plea was rejected. If the defendant had pleaded guilty after being included on the list of suspects, the prison sentenced ranged from 25 to 30 years. If the defendants had pleaded guilty before being included on the list of suspects, the prison sentenced ranged from 20 to 24 years, see Republic of Rwanda, Gacaca Courts in Rwanda, 101-103.

${ }^{112}$ In the following discussion, specific interviews are referenced as interview with M1, M2, M3 and so on. The letter M is short for "Maman," a term used by Rwandan professionals who assisted with the recruitment of the interviewees when referring to the women.

${ }^{113}$ Interview conducted with M22, January 9, 2015.

${ }^{114}$ Interview conducted with M7, December 19, 2015.

${ }^{115}$ Interview conducted with M21, January 7, 2016.

${ }^{116}$ Interview conducted with M20, January 4, 2016. 
M20 had been raped and viciously sexually tortured by at least ten men, of whom many were her neighbours. Her perpetrators raped her and sexually ridiculed her in front of a group of schoolboys to "demonstrate to those kids how to rape a woman." M20 explained that she had not submitted her case herself, but "had been summoned in front of the gacaca court by force" after her rape had been exposed by some people in prison.

Two of the women whose perpetrators had received less than a life sentence - they had been sentenced to 28 and 30 years in prison - were not fully satisfied with the verdict in their cases, since they thought the penalties were too lenient. ${ }^{117}$ M17 had submitted her case at gacaca because she had been "promised that those who had committed crimes were going to be punished."118 M17 had been raped and assaulted by several perpetrators, but could only indict two of them. ${ }^{119}$ One of them had fled the country; the other one was sentenced to 30 years in prison. M17 did not feel that the sentence of 30 years was enough. Instead, she "wanted him to go to prison for life."120 M17 mentioned during her interview that she was scared that her perpetrator would return home and murder her, which might have been the reason why she had hoped for a life sentence of her perpetrator. ${ }^{121}$

While for most women the punishment of their perpetrators was crucially important, not all women appreciated the prison sentence of their perpetrators in the same manner. For example, one woman (M9) explained:

The prosecution can find evidence to convict someone without them having to confess but it does not make me happy. I did not think that sending people to prison was my main objective. ${ }^{122}$

M9 had not submitted her case herself, but her community had done so during the informationgathering phase of gacaca. M9 had been raped by several men, but only three of them were known to her. Gacaca acquitted two of them of the rape charges, but sentenced the third one, who had fled the country, in absentia to 30 years. Before fleeing the country, the perpetrator had visited M9 and had asked her for forgiveness. Instead of punishment of her perpetrators, M9 was hoping for someone to facilitate a meeting to enable an exchange of apology and forgiveness:

The government has all the rights to punish their people the way they feel is right. I do not give orders to the government but if I were the commander, I would tell them to forgive him. I just wish that we could have someone who could organize that we meet with those people. They should help us come together and they would ask us for forgiveness and we would forgive them. We would have good relationships after that. ${ }^{123}$

Those women who appreciated the punishment of their perpetrators provided diverse insights into why the sentence was important to them. Several women explained that the punishment in the form of imprisonment helped to provide some psychological and physical safety. For example, one woman (M8), whose perpetrator had been sentenced to life imprisonment, explained:

\footnotetext{
${ }^{117}$ This is consistent with Henry's research with survivors of sexual violence who testified at the International Criminal Tribunal for the former Yugoslavia (ICTY): light sentencing represented a minimisation of suffering of the women, see Henry, Witness to Rape, 131.

${ }^{118}$ Interview conducted with M17, December 29, 2015.

${ }^{119}$ The other perpetrators were unknown to M17, which is why she could not include them in her case at gacaca.

${ }^{120}$ Interview conducted with M17, December 29, 2015.

${ }^{121}$ Further below, this article discusses why women appreciated specific punishments, including for reasons of safety and validation.

${ }^{122}$ Interview conducted with M9, December 28, 2015.

${ }^{123} \mathrm{Ibid}$.
} 
Gacaca has put him away and I was relieved because every time I saw him, I thought that he was probably going to hurt me again. I sometimes feared to walk on the street because I did not want to cross paths with him. ${ }^{124}$

While M8 had submitted her case because she "wanted ... [her perpetrator] to be punished," she had also hoped that he "would ask ... [her] for forgiveness in front of the authorities so that they could be aware of it." However, the perpetrator of M8 neither confessed nor apologized.

Several women mentioned the need for retribution and commented that it was important to them that wrongdoing was sanctioned. For example, one woman explained:

I was kept strong by the idea that justice was coming to help Rwandans... I see justice as helping someone suffering from injustice. The person who is found guilty of a crime needs to be punished and the one who is not found guilty should go home... Whoever has committed a crime needs to be punished for it. ${ }^{125}$

Another woman (M14) explained:

I wanted them to punish him. I wanted to make sure that he gets punished for what he did to me. I was living in sorrow and I wanted to be sure that we have some laws to protect us. ${ }^{126}$

M14 was nineteen years old when her perpetrator had raped and assaulted her in front of her mother and some other women. After the assault, her perpetrator had threatened that he would return to rape her and finally kill her. M14 survived because she fled from the area and hid in the country until it was safe enough for her to return.

In the eyes of some women, the sanctioning of wrongdoing was important for various reasons, including to vindicate the victims, as well as to demonstrate that the culture of impunity had been stopped and the rule of law had been re-established in Rwanda. For example, one woman (M13) explained:

There were two positive things that happened during gacaca even though they are not that positive. Seeing the person who has hurt you being punished is one and the fact that the people understood that whoever commits a crime is going to be punished is the second one. During the genocide, they were saying that it was the end for the Tutsis, and for a while we thought that there was never going to be anyone to vindicate us or follow up on what happened to us. ${ }^{127}$

Another woman commented that the sanctioning of wrongdoing helped to facilitate the coexistence of perpetrators and survivors:

...Whoever has committed a crime needs to be punished for it. The culture of impunity needs to be abolished... There is no longer a feeling of guilt because those who were found guilty of crimes have realized that it was something they should not have done to another human being in the first place. If the person was sentenced to some time in prison and they have come out, when you meet on the street, they say hello to you and they continue their way and you go on your way. ${ }^{128}$

\footnotetext{
${ }^{124}$ Interview conducted with M8, December 28, 2015.

${ }^{125}$ Interview conducted with M6, December 19, 2015.

${ }^{126}$ Interview conducted with M14, December 29, 2015.

${ }^{127}$ Interview conducted with M13, December 29, 2015.

${ }^{128}$ Interview conducted with M7, December 19, 2015.
} 
Some women commented that the punishment of sexual violence at gacaca helped to validate the harm they had experienced and supported their vindication. For example, one woman explained:

One day, the gacaca courts were introduced. I still did not feel human yet at that point. People later understood that rape is a crime that cannot be forgiven. Before that, they would ridicule me and make me feel like it was my fault. People finally got to realize that rape was a serious crime and that it was punishable by law. People used to talk about it as a hot topic and they would make fun of me. They would tell everyone in the neighborhood about it and those people would tell me. ${ }^{129}$

M15 had been raped in front of her community by a group of young men from her neighborhood. Some of them were her neighbor's sons who she used to feed at her house before the genocide.

Another woman (M1), whose perpetrator had been sentenced to life imprisonment, ${ }^{130}$ said:

Gacaca went well. I was really upset by the first trial, but I got justice during the appeal. I was not even interested in getting some reparation for the disability he gave me. I had had enough with people whispering about me because I had been raped. People took it as if I was a prostitute... I am happy that he was punished. People were accusing us of being sluts who would have sex with men during the genocide. ${ }^{131}$

M1 had been gang raped by a group of man, of which she knew only one man. She had been suffering from the direct repercussions of the assault as well as from the reactions of her community to the rape. She explained that the one perpetrator whom she knew

would go and brag about it to people. He would always tell them that he has another wife who he has sex with in the bushes. Those people whom I asked for refuge started rubbing in my face that the man who raped me was always bragging about it to them.

M1 explained that she had been married before she was raped, but her husband left her and remarried because he could not accept what had happened to his wife. ${ }^{132}$ The two comments of M15 and M1 demonstrate that in the women's view, the punishment of their perpetrators relieved the women from the allegation that they were responsible themselves for what had happened to them and that they had willingly offered sexual services to the other side. ${ }^{133}$

Many women commented on the impact that the punishment of their perpetrator had on their lives. Women's views on this impact were diverse. Several women explained that the punishment of their perpetrator in form of imprisonment provided some safety, such as M8:

I used to feel scared of meeting him on the street, while I would be walking with my husband, but I no longer have to worry about that because of gacaca. It has lifted a weight off my shoulder. There was no other way for me to have some peace of mind, except maybe if I fled and went somewhere far away. Gacaca was important to me because it has brought a sense of security and I can go and live anywhere without fearing for my life. ${ }^{134}$

\footnotetext{
${ }^{129}$ Interview conducted with M15, December 29, 2015.

${ }^{130}$ Even though M1 had been gang raped, only one of her perpetrators was known to her. Therefore, she could submit her case only against that one man at gacaca.

${ }^{131}$ Interview conducted with M1, December 18, 2015.

${ }^{132}$ Ibid.

${ }^{133}$ Similarly, Nowrojee had found in her interviewees with Rwandan survivors of sexual violence who testified at the ICTR that they wanted the ICTR to condemn the violence committed against them and to acknowledge that "as rape survivors ... [the women] did not collaborate willingly with genocidaires who kept them alive to rape," Nowrojee, Your Justice Is Too Slow, 111.

${ }^{134}$ Interview conducted with M8, December 28, 2015.
} 
Similarly, M14, whose perpetrator was sentenced to life imprisonment, explained:

I used to always be on edge that he would come after me. His sentence reassured me that he would never come back. ${ }^{135}$

Even though not all prison sentences imposed by gacaca could be executed because many perpetrators had fled Rwanda, already the sentencing in absentia had a positive impact on women's psychological state. For example, M3 had been raped by three men at different times during the genocide. She had raised her case against only one of her perpetrators. ${ }^{136}$ Since he had fled the country, he was sentenced in absentia to life imprisonment. When asked how she felt about the judgment of her perpetrator, M3 responded:

I was happy to hear it. He has committed the crime and even though he was not present, ${ }^{137}$ I was happy to hear that he was being sentenced. I was relieved from a burden that I was carrying..$^{138}$

M3's reaction to the verdict in her case shows that for some women the condemnation of the violence, expressed by the life sentence, might be more or just as important as the actual execution of the punishment to vindicate the victim-survivor.

Some women commented on further positive psychological effects that the sentencing of their perpetrator had on their recovery, including strength, motivation and the ability to forgive. For example, one woman (M16) explained:

I was happy and [the punishment] assured me that my life was able to keep moving on to the extent that I started to feel confident enough to take on something big such as defending other people. It provided me with more strength and I work hard today. It created a positive result. ${ }^{139}$

M16 had been kept in house with 30 other women and their children, who were raped daily over an extended period. All women and children were killed at one point in time except from M16. She had raised her case "to get rid of the stigma... [she] was experiencing from everyone around... [her]" and to "fight for justice in the name of all the victims... [she] was with". M16 had submitted her case against a group of 30 men who were all sentenced to life imprisonment with special provisions. ${ }^{140}$ M16 worked as a gacaca judge herself and assisted other survivors or sexual violence to report their cases. Furthermore, she was involved in creating a support group for genocide survivors.

The comments of some women suggest that the feeling of safety due to the imprisonment of their perpetrators supported their psychological recovery. For example, M8, who had previously spoken about her fear of meeting her perpetrator in the street, explained:

Gacaca came and sent them all to prison and that helped me so much and it gave me peace of mind. That was the reason why I started thinking clearly and realized that I have to forgive. ${ }^{141}$

${ }^{135}$ Interview conducted with M14, December 29, 2015.

${ }^{136}$ One of her perpetrators had apologized to her after the genocide and M3 did not report him at gacaca; another perpetrator had died.

${ }^{137}$ The accused had fled the Rwanda prior to the gacaca trial but was sentenced in absentia.

${ }^{138}$ Interview conducted with M3, December 18, 2015.

${ }^{139}$ Interview conducted with M16, December 29, 2015.

${ }^{140}$ About half of the perpetrators had fled the country and were sentenced in absentia. 14 were present at the trial. Initially, all men had been acquitted, but M16 appealed the judgment 4 times. The $5^{\text {th }}$ and final appeals court concluded with the sentencing of all defendants.

${ }^{141}$ Interview conducted with M8, December 28, 2015. Most women discussed the topic of forgiveness at some stage during their interview, which the author is planning to analyse in a separate publication. 
Those women who felt that the sentences given to their perpetrators were too lenient appeared to suffer emotionally from the outcome of their trials, since the verdict did not validate their experiences in the way they had hoped and/ or did not fully alleviate their concerns for safety. For example, M17, whose perpetrator was sentenced to 30 years and not to life imprisonment as hoped by M17, explained:

As a Christian, I am okay with forgiving them so that they can come back home but then again, I am worried about my future. I am not able to work as I should. I am also worried that if they came back home, they would murder us... I was stabbed when they were raping me. I was trying to fight them and they stabbed me. That hurts me so much. That feeling is never going to leave me. I am not able to work and I need to earn a living. That is what makes me so upset. When it comes to the law, if it is their time to get out of jail, they will have to go home and there is nothing I can do about that. ${ }^{142}$

The woman whose perpetrator was first convicted but then acquitted in an appeals process spoke about how devastating the second trial and its outcome was for her:

When I went back to trial, they did not believe what I was saying. They made me feel like I was crazy... I was not happy with the court's second verdict. They concluded that the man was not guilty... The people in his family and the other people who were in the attack defended him and gave him an alibi... I cannot find anything good to say about Gacaca because they would choose some of their own people and say that they did not participate in attacks and they would become members of the jury. ${ }^{143}$

While many women spoke about the positive impact of the judgment of their perpetrator on their own recovery, some of the women explained that punishment alone did not satisfy the needs associated with the harm caused by the sexual violence, including medical assistance and other forms of reparations. For example, when asked about how she felt about the life sentence of her perpetrator, one woman explained:

No happiness can come out of this situation. I felt relieved though, because [before] I would see him on the street and feel scared. My problems did not stop when he went to jail. We just have to hang in there, but the truth is that those people have stripped us of our dignity.

I: What problems are you talking about?

M19: Being raped has left me handicapped... We were lucky to have some military doctors come here to give us some medical care... I had a small rock that was stuck in my ear from that time... When that horrible man was raping me, he threw my back out. Those military doctors helped us a lot. They removed that rock and I am now able to hear from that ear. They also fixed my back and it is now better. I was mentally broken after the trial, but I am doing better now. ${ }^{144}$

Another woman (M11) explained:

Gacaca happened and the criminals were sent to jail but nothing else happened... We did not have the right to claim any reparations at that time. They would just tell us that we have had our case and that was it. We did not have anyone to represent us and claim that for us. Whenever the trial would be over, that would be the end of it. They would bring the criminal to prison and we would go back home. ${ }^{145}$

\footnotetext{
${ }^{142}$ Interview conducted with M17, December 29, 2015.

${ }^{143}$ Interview conducted with M4, December 19, 2015.

${ }^{144}$ Interview conducted with M19, January 4, 2016.

${ }^{145}$ Interview conducted with M11, December 28, 2015.
} 
Like M11, several other women mentioned that they had hoped for gacaca to enable reparations or various forms of support.

\section{Perpetrators Taking Responsibility}

Many women spoke about the need to hear confessions, apologies and requests for forgiveness, which are summarized under "perpetrators taking responsibility" in this article. Some women also spoke about wanting perpetrators to explain their actions or feel ashamed for what they had done, which also fits the concept of taking responsibility, but this was discussed to a lesser extent.

Out of the 23 women, 17 explained that at least one of their perpetrators denied all charges against him and did thus not assume any responsibility. Less than half of all women spoke about at least one of their perpetrators confessing, apologizing or asking them for forgiveness. Women placed high value on when, where and how their perpetrator assumed responsibility, including whether it was done before, during or after gacaca, whether other people were present or not, and whether the women perceived the demonstration of responsibility as genuine or as a strategy of the perpetrator to reduce his gacaca sentence. Some women did not accept the confession, apology or request for forgiveness voiced by their perpetrator, because the women did not consider the time, forum, circumstances or reasons to be appropriate. Several women explained that in their view their perpetrators only pretended to take responsibility to avoid or reduce their prison sentence. For example, one woman explained:

He then kneeled down in court and started apologizing. I asked them to consider all the years that had gone by from 1994 to 2008 and he was only asking for forgiveness because we were in court. They asked him why he decided to rape me and what he wanted to get out of it, and all he said was that he was sorry and he understood that he had committed a big crime and that he wanted me to forgive him. In the meantime, before the trial started, he had sent someone to me to ask me what I wanted. He wanted to buy my silence with money. When he asked me for forgiveness, I thought about the fact that I could have died, that I was lucky to still be alive, that he could have ruined my life and left me to deal with the consequences, and I did not say anything. I told him that he had so much time where he could have asked me to forgive him and he only sent someone to me after hearing that there was a letter. He did not come to me on his own will. ${ }^{146}$

Other women highlighted that a confession, apology or request for forgiveness voiced in private was not acceptable to them, since they viewed it as a strategy of their perpetrator to prevent the truth about them to come out. For example, one woman said:

My aggressor was an Adventist. I asked around and found out that he was an Adventist and that he was a pastor. He was disguising as a good person and I wanted to expose him in front of God. He sent some members of his church to beg me to forgive him and keep quiet and I refused. I told those people what he had done to me and the number of people he had killed. I needed them to know who their pastor really was. I did not expect anything more. I just wanted him to pay for what he had done to me. I had begged him to pardon me [during the genocide] and he didn't. I was not going to forgive him either. ${ }^{147}$

As indicated by this comment, it was important to many women that their perpetrators assumed responsibility in public and not only in private.

Some women wanted to know from their perpetrators why they had been targeted, which appeared to help the women assess whether their perpetrators were willing to assume active responsibility. For example, M13 had submitted her case against a group of men "so that she could ask them why they did what they did to... [her]."148

\footnotetext{
${ }^{146}$ Interview conducted with M6, December 19, 2015.

${ }^{147}$ Interview conducted with M19, January 4, 2016.

${ }^{148}$ Interview conducted with M13, December 29, 2015.
} 
M13: I asked them that questions... and they would just tell me that it was Satan who pushed them to do it. They said that Satan used the government that was in place at the time and the government ordered them to do what they did.

I: How did you take such a response?

M13: That response was not satisfactory to me because as a human, I know that a human being is capable of differentiating what is good from what is bad. The court agreed with me that their answer was not accurate and that is why they were punished. ${ }^{149}$

M13's comment suggests that it was important for her that her perpetrators adequately assumed individual responsibility rather than blaming others or external factors.

Some women appreciated confessions, apologies and requests for forgiveness if given under circumstances that they considered appropriate. Some of these women spoke about the positive impact on their personal recovery when their perpetrators genuinely assumed responsibility, including that it gave them strength and helped them to forgive. For example, M21 explained:

The one who asked me for forgiveness did it from prison... It was not easy for me to go there but I finally got the courage to do it. I went there and he asked me for forgiveness in front of many people. He did it in front of the people who had come to visit and other prisoners. His wife was also there. That gave me more strength and made me feel relieved... I sincerely forgave him... He had not mentioned [what he had done] during Gacaca but he publicly confessed to everything there and then. ${ }^{150}$

Similarly, M20, who had been raped and viciously sexually tortured by a group of men from her neighborhood, reported:

They were sentenced to life in solitary confinement. However, they humbly begged me for forgiveness and that made me feel happy... What made me sad was the fact that many of them were our neighbors who had worked at our house. I kept asking them if there was something I had done to offend them. "Wasn't I a kind person to you?" I asked and they told me that they were disappointed in their behavior. I forgave them and refused to receive any of the reparations that they had been ordered to pay me. I truly forgave them and that was the most important thing to do. I was very inspired by being asked for forgiveness. That created something new in me. ${ }^{151}$

As previously mentioned, 17 women spoke about perpetrators denying all charges raised against them. Many women commented on a general lack of responsibility shown by the accused during gacaca, including in their own trial and in other women's trials. For example, one woman explained:

In all the trials that I have followed, no one has ever confessed to raping someone. Many people have come forward to confess that they have killed someone, but no one has ever said that they raped someone and they were sorry for it. ${ }^{152}$

Some women spoke about how difficult it was for them that their perpetrators did not take responsibility. For example, when asked about what stood out as a difficult experience at gacaca, one woman (M19) mentioned "the difficult part of the trial was that he refused to confess and beg me for forgiveness." ${ }^{153}$ Like M19, many other women had hoped that their perpetrator would

\footnotetext{
${ }^{149}$ Ibid.

${ }^{150}$ Interview conducted with M21, January 7, 2016.

${ }^{151}$ Interview conducted with M20, January 4, 2016.

${ }^{152}$ Interview conducted with M5, December 19, 2016.

${ }^{153}$ Interview conducted with M19, January 4, 2016.
} 
assume responsibility. The responses of some of the women who had previously highlighted the need for punishment and imprisonment of their perpetrator suggest that punishment alone was not sufficient to meet their justice interests, but that they also desired a demonstration of responsibility. ${ }^{154}$ For example, M8 explained:

I wanted them to take him out of my sight and imprison him, but I thought that if he could come and ask me for forgiveness, I was going to forgive him. He did not ask me for forgiveness and it was a shame because I could have forgiven him if he did ask me to. What I wanted was for him to ask me for forgiveness in front of the authorities so that they could be aware of it. He never did any of that. After spending some time in prison, he appealed and I thought that he was going to ask for forgiveness during his appeal, but he instead insisted that he had never done anything to harm any Tutsi. When he said that, I got traumatized and upset... To this day, none of them has come to me and asked for forgiveness. I still wonder how I was going to forgive people who did not ask me for forgiveness. ${ }^{155}$

The comments of some women suggest that perpetrators assuming responsibility might be even more important than their punishment. For example, M1, who had previously highlighted her appreciation of the punishment of her perpetrator, explained:

What hurt me was that he never even tried to apologize to me. I was not happy that he was sent to prison. If he had confessed and begged for forgiveness, I would have forgiven him. He denied all charges and tried to humiliate me again, so I guess he chose to go to prison instead..$^{156}$

As demonstrated by the comments above, some women not only desire(d) for perpetrators to assume responsibility, but also appeared to be willing, some even keen, to forgive if their perpetrator apologized.

The women had different ideas on whether a confession, apology or request for forgiveness should affect the perpetrator's prison sentence. Some women commented that while an apology would positively influence their personal attitude toward the perpetrators, it should not make a difference to the original prison sentence imposed by the gacaca judges. For example, one woman explained:

The thing is that if he came to me and apologized, I would also forgive him because I have already forgiven his family. You forgive him, but he still has to go to prison and pay for his crime. ${ }^{157}$

Another woman suggested that a voluntary demonstration of responsibility should positively affect the perpetrator's standing in the community and future options, but that some form of punishment was still necessary:

I think that if someone voluntarily confesses to their crime, they should be corrected and be given an opportunity to come back to the society as a better Rwandan citizen who is ready to make better choices. ${ }^{158}$

\footnotetext{
${ }^{154}$ This point is supported by de Brouwer and Ruvenaba who found in their study with Rwandan genocide survivors that survivors were more satisfied with the punishment of their perpetrators when the latter had also "confessed to their crimes and had genuinely asked for forgiveness," see de Brouwer and Ruvebana, The Legacy of the Gacaca Courts in Rwanda, 951.

${ }^{155}$ Interview conducted with M8, December 28, 2015.

${ }^{156}$ Interview conducted with M1, December 18, 2015.

${ }^{157}$ Interview conducted with M3, December 18, 2015.

${ }^{158}$ Interview conducted with M13, December 29, 2015.
} 
Some women commented that a genuine request for forgiveness could warrant the replacement of their perpetrators' prison sentence. For example, one woman said "I feel like if he was willing to come and ask me for forgiveness, I would ask them to release him [from prison]." ${ }^{159}$ As this comment demonstrates, an apology or request for forgiveness seemed to replace the need for punishment of their perpetrator in the view of some women.

\section{Conclusion}

This article provided insight into how women who had suffered sexual violence during the genocide in Rwanda experienced justice through the gacaca courts, including their understandings of justice and how well gacaca assisted them in addressing their post-genocide justice interests. The article focused especially on two elements of justice categorized as punishment, and the perpetrator taking responsibility.

Justice, for most of the women, was defined in terms of the punishment of their perpetrator by gacaca. The women's emphasis on punishment was driven by several underlying needs that the women articulated, including safety, retribution, validation and vindication. This range of needs shows some consistency with the findings of other studies with survivors of sexual violence in different contexts. ${ }^{160}$ However, the relatively high number of women who discussed retribution in this research differs from other studies, including Nowrojee's research with Rwandan women who had testified at the ICTR, and is a question for further analysis. ${ }^{161}$

In addition to the punishment of their perpetrator, it was important for many women to also see the perpetrator taking some form of responsibility for what they had done including by way of an apology or request for forgiveness. Perpetrators assuming responsibility appeared to constitute an alternative way for the women to experience justice through validation and vindication. Whether women accepted a demonstration of responsibility as genuine depended on various factors, including the timing, forum and circumstances under which perpetrators apologized or asked for forgiveness.

The women who participated in this research valued gacaca particularly for its role in providing punishment for the perpetrators. The life sentences of most of the perpetrators appeared to alleviate women's safety concerns, since women felt assured that they would never have to meet or be threatened by their perpetrators again. The need for validation and vindication seemed to be met, at least to some extent, because the sentence of life imprisonment constituted the maximum penalty, which signaled to the women that the Rwandan government acknowledged the severity of crimes of sexual violence. Those women whose perpetrators received a lesser sentence than life imprisonment were less satisfied by the justice meted out by gacaca. These women continue to worry about their safety and still long for validation and vindication.

While most women appreciated gacaca's handling of punishment, the courts' contribution towards reconciliation was less valued. Some women mentioned perpetrators confessing, apologizing and asking for forgiveness at gacaca; however, most of the women commented on a lack of responsibility being facilitated during gacaca, as evidenced by the following discussion:

I: Do you think gacaca has helped you in any way to make those people ask you for forgiveness?

M10: I did not mention anything about that. They were punished but there was nothing done about asking for forgiveness. ${ }^{162}$

\footnotetext{
${ }^{159}$ Interview conducted with M12, December 28, 2015.

${ }^{160}$ Daly, Reconceptualizing Sexual Vicimization and Justice, 388; Koss, Restoring Rape Survivors, 209; Herman, Justice From the Victim's Perspective; Henry, Witness to Rape; Sharratt, Gender, Shame and Sexual Violence; Nowrojee, Your Justice Is Too Slow; Uwigabye, Gacaca and the Treatment of Sexual Offenses. The findings in these various studies vary in terms of which specific justice needs were important to the survivors who were considered in each study. For example, some studies indicated that punishment of perpetrators was a priority for survivors, while survivors in other studies did not seem to place high value on punishment, but prioritised accountability, validation, vindication or truth.

${ }^{161}$ Nowrojee, Your Justice Is Too Slow, 111.

${ }^{162}$ Interview conducted with M10, December 28, 2015.
} 
Some of those women whose perpetrators did confess and/or apologize at gacaca did not consider these confessions and apologies as a genuine assumption of responsibility, but rather as a strategy of the perpetrator to have the prison sentence reduced. Gacaca's contribution to ending impunity while falling short of promoting reconciliation has been highlighted previously by other researchers who evaluated the achievements of gacaca. ${ }^{163}$ While the provision of punishment seemed to have had some positive effects on many women (for example, women commented that seeing their perpetrator punished lifted a burden from them, facilitated forgiveness, made them feel safe, etc.), the refusal of perpetrators to take responsibility appeared to aggravate women's individual recovery. Many women commented on how difficult it was for them that their perpetrators denied everything and how they had wished to hear a confession or even better, a request for forgiveness. Some women shared their thoughts on how they believed they would respond to genuine expressions of responsibility, including that they would forgive and even try to have their perpetrators pardoned. These comments suggest that at least some Rwandan victim-survivors might contemplate reconciliation with their perpetrators if the latter assumed responsibility in a forum and manner that the women considered as appropriate.

The analysis of the women's justice interests and evaluation of their court process experience has implications beyond Rwanda and gacaca. This research adds to a better understanding of justice interests of victim-survivors of conflict-related sexual violence, giving insight into why affected women may value punishment and perpetrator responsibility as a form of justice. The research also provides some ideas for the design of future justice processes dealing with sexual violence. Victim-survivors' requests for punishment require analysis to understand the range of underlying justice interests and needs, such as safety, vindication and validation. In contexts where punishment of perpetrators may prove difficult, justice processes should consider alternative ways to meet victim-survivors' underlying interests and needs. This research showed, for example, that the need for validation and vindication can be assisted by perpetrators assuming responsibility for their actions. Therefore, future justice measures could be designed in a manner that facilitates the processes of perpetrators demonstrating responsibility towards their victims.

\section{Bibliography}

African Rights. Broken Bodies, Torn Spirits - Living with Genocide, Rape and HIVIAIDS. Kigali: African Rights, April 2004.

Amick, Emily. "Trying international crimes on local lawns: the adjudication of genocide sexual violence crimes in Rwanda's Gacaca courts." Columbia Journal of Gender and Law 20, no. 2 (2011), 1-97. https://doi.org/10.3366/nor.2011.0002

Amnesty International. Rwanda: "Marked for Death," Rape Survivors Living with HIVIAIDS in Rwanda. USA: Amnesty International, 2004.

"Rwanda: Abolition of the Death Penalty." Public statement, July 27, 2007.

Amstutz, Mark R. "Is Reconciliation Possible After Genocide?: The Case of Rwanda." Journal of Church and State 48, no. 3 (2006), 541-565. https://doi.org/10.1093/jcs/48.3.541

AVEGA- AGAHOZO. Survey on Violence against Women in Rwanda. Kigali, 1999.

Bastick, Megan, Karin Grimm, and Rahel Kunz. Sexual Violence in Armed Conflict. Geneva: Geneva Centre for the Democratic Control of Armed Forces, 2007.

Bornkamp, Paul Christoph. Rwanda's Gacaca Courts. New York: Oxford University Press, 2012. https://doi.org/10.1093/acprof:oso/9780199694471.001.0001

Brehm, Hollie Nyseth, Christopher Uggen, and Jean-Damascène Gasanabo. "Genocide, Justice, and Rwanda's Gacaca Courts." Journal of Contemporary Criminal Justice 30, no. 3 (2014), 333352. https://doi.org/10.1177/1043986214536660

\footnotetext{
${ }^{163}$ For example, Lambourne found that gacaca did not fulfil its aims to promote reconciliation as well as justice, Lambourne, Transitional Justice after Mass Violence, 20-22; Lambourne, Transformative Justice, Reconciliation and Peacebuilding, 27-28. de Brouwer and Ruvebana also discuss a lack of accountability and confirm that "only a relatively small number of cases [13\% of 1,681,648 cases leading to convictions] resulted in perpetrators pleading guilty and apologizing for their crimes... of which some apologies may have been sincere and others not." de Brouwer and Ruvebana, The Legacy of the Gacaca courts in Rwanda, 954-956, 962.
} 
Brounéus, Karen. "Truth-Telling as Talking Cure? Insecurity and Retraumatization in the Rwandan Gacaca Courts." Security Dialogue 39, no. 1 (March 1, 2008), 55-76. https://doi. org/10.1177/0967010607086823

Byamukama, Shivon. Justice in the Aftermath of the 1994 Rwanda Genocide: A Study of Gacaca Courts. Glasgow: Glasgow Caledonian University, 2008.

Clark, Phil. "After Genocide: Democracy in Rwanda, 20 years on." Juncture 20, no. 4 (2014), 308-311. https://doi.org/10.1111/j.2050-5876.2014.00771.x

. The Gacaca Courts, Post-Genocide Justice and Reconciliation in Rwanda. Cambridge and New York: Cambridge University Press, 2010.

. "The Rules (and Politics) of Engagement: The Gacaca Courts and Post-Genocide Justice, Healing and Reconciliation in Rwanda." In After Genocide: Transitional Justice, Post-Conflict Reconstruction and Reconciliation in Rwanda and Beyond, edited by Phil Clark and Zachary D. Kaufman, Chapter 15. New York: Columbia University Press, 2009.

Corey, Allison and Sandra F. Joireman. "Retributive Justice: The gacaca Courts In Rwanda." African Affairs 103 (2004), 73-89. https://doi.org/10.1093/afraf/adh007

Daly, Kathleen. "Reconceptualizing Sexual Vicimization and Justice." In Justice for Victims: Perspectives on Rights, Transition and Reconciliation, edited by Inge Vanfraechem, Antony Pemberton and Felix Mukwiza Ndahinda, 378-395. London and New York: Routledge, 2014.

Daly, Kathleen and Sarah Curtis-Fawley. "Justice for Victims of Sexual Assault: Court or Conference?" In Gender and Crime: Patterns of Victimization and Offending, edited by Karen Heimer and Candace Kruttschnitt, 230-265. New York: New York University Press, 2006.

de Brouwer, Anne-Marie, Sandra Ka Hon Chu, and Samer Muscati. The Men Who Killed Me: Rwandan Survivors of Sexual Violence. Vancouver: Douglas \& McIntyre, 2009.

de Brouwer, Anne-Marie and Etienne Ruvebana. "The Legacy of the Gacaca Courts in Rwanda: Survivors' Views." International Criminal Law Review 13, no. 5 (2013), 937-976. Accessed October 4, 2014. https://doi.org/10.1163/15718123-01305001

Degni-Ségui, René. Report on the situation of human rights in Rwanda submitted by Mr. René DegniSégui, Special Rapporteur of the Commission on Human Rights, under paragraph 20 of resolution S-3/1 of 25 May 1994. January 29, 1996, Agenda Item 10. UN Doc. E/CN.4/1996/68.

Des Forges, Alison. Leave None to Tell the Story: Genocide in Rwanda. New York, Washington, London, Brussels: Human Rights Watch, 1999.

Donavan, Paula. "Rape and HIV/AIDS in Rwanda." The Lancet 360, no. 1 (2002), 17-18. https://doi. org/10.1016/S0140-6736(02)11804-6

Haffajee, Rebecca L. "Prosecuting Crimes of Rape and Sexual Violence at the ICTR: The Application of Joint Criminal Enterprise Theory." Harvard Journal of Law \& Gender 29 (2006), 201-221.

Haskell, Leslie. Justice Compromised - The Legacy of Rwanda's Community-Based Gacaca Courts. USA: Human Rights Watch, 2011.

Henry, Nicola. "Witness to Rape: The Limits and Potential of International War Crimes Trials for Victims of Wartime Sexual Violence." International Journal of Transitional Justice 3, no. 1 (2009), 114-134. Accessed September 27, 2012. https://doi.org/10.1093/ijti/ijn036

Herman, Judith Lewis. "Justice From the Victim's Perspective." Violence Against Women 11, no. 5 (2005), 571-602. Accessed February 20, 2014. https://doi.org/10.1177/1077801205274450

Herrmann, Judith. "A Critical Analysis of the Transitional Justice Measures Incorporated by Rwandan gacaca and their Effectiveness." James Cook University Law Review 19 (2012), 90112.

. "Experiences, Challenges, and Lessons Learned - Interviewing Rwandan Survivors of Sexual Violence." Griffith Journal of Law \& Human Dignity 5, no. 1 (2017), 165-188.

Human Rights Watch. Struggling to Survive: Barriers to Justice for Rape Victims in Rwanda. New York: Women's Rigths Division, 2004.

Kagire, Edmund. "Genocide against the Tutsi: It's now Official." The EastAfrican, February 1, 2014. Accessed July 24, 2018. http://www.theeastafrican.co.ke/news/UN-decides-it-is-officiallygenocide-against-Tutsi/2558-2169334-x8cirxz/index.html.

Kaitesi, Usta. Genocidal Gender and Sexual Violence. Cambridge: Intersentia, 2014. 
Kaitesi, Usta and Roelof Haveman. "Prosecution of Genocidal Rape and Sexual Torture before the Gacaca Tribunals in Rwanda." In Victimological Approaches to International Crimes: Africa, edited by Rianne Letschert, Roelof Haveman, Anne-Marie De Brouwer and Antony Pemberton, 385-406. Cambridge, Antwerp and Portland: Intersentia, 2011.

Knust, Nandor. Strafrecht und Gacaca. Berlin: Duncker \& Humblot, 2013.

Koss, Mary P. "Restoring Rape Survivors." Annals of the New York Academy of Sciences 1087, no. 1 (2006), 206-234. https://doi.org/10.1196/annals.1385.025

Lambourne, Wendy. "Transformative Justice, Reconciliation and Peacebuilding." In Transitional Justice Theories, edited by Susanne Buckley-Zistel, Teresa Koloma Beck, Christian Braun, and Friederike Mieth, 19-39. London: Routledge, 2014.

---------. "Transitional Justice after Mass Violence: Reconciling Retributive and Restorative Justice." In Julius Stone: A Study in Influence, edited by Helen Irving, Jacqueline Mowbray and Kevin Walton, 214-237. Sydney: The Federation Press, 2010.

Lambourne, Wendy, and Vivianna Rodriguez Carreon. "Engendering Transitional Justice: a Transformative Approach to Building Peace and Attaining Human Rights for Women." Human Rights Review (2015), 1-23.

Lambourne, Wendy and Lydia Wanja Gitau. "Psychosocial Interventions, Peacebuilding and Development in Rwanda." Journal of Peacebuilding and Development 8, no. 3 (2013), 23-36. https://doi.org/10.1080/15423166.2013.859933

Mani, Rama. Beyond Retribution: Seeking Justice in the Shadows of War. Cambridge and Malden: Polity Press ; Blackwell Publishers Inc., 2002.

. "Integral Justice for Victims." In Justice for victims, edited by Inge Vanfraechem, Antony Pemberton and Felix Mukwiza Ndahinda, 183-209. London and New York: Routledge, 2016.

Matthews, Roger. "Punitiveness." In The SAGE Dictionary of Criminology, edited by Eugene McLaughlin and John Muncie, Pages. London and Thousand Oaks: SAGE Publications Limited, 2013.

Mukamana, Donatilla, and Anthony Collins. "Rape Survivors of the Rwandan genocide." International Journal of Critical Psychology 17 (2006), 140-166.

Mullins, Christopher W. “'We Are Going to Rape You and Taste Tutsi Women': Rape during the 1994 Rwandan Genocide." The British Journal of Criminology 49, no. 6 (2009), 719-735. https://doi.org/10.1093/bjc/azp040

Nagarajan, Chitra. "An appraisal of Rwanda's response to survivors who experienced sexual violence in 1994." Wagadu 10 (2012), 108-131.

Nduwimana, Françoise. The Right to Survive Sexual Violence, Women and Hiv/Aids. Montreal: International Centre for Human Rights and Democratic Development, December 2004.

Nowrojee, Binaifer. Shattered Lives - Sexual Violence during the Rwandan Genocide and its Aftermath. USA: Human Rights Watch, 1996.

-------.. "'Your Justice Is Too Slow' Will the International Criminal Tribunal for Rwanda Fail Rwanda's Rape Victims?" In Gendered Peace, edited by Donna Pankhurst, 107-136. New York and Oxon: Routlege and UNRISD, 2008.

Omaar, Rakiya, Théodore Nyilinkwaya, Carla Ferstman, and Jürgen Schurr. Survivors and PostGenocide Justice in Rwanda. London and Kigali: African Rights and REDRESS, November 2008.

Organization for African Unity. Rwanda: The Preventable Genocide. OAU, July 2000.

Republic of Rwanda. Gacaca Courts in Rwanda. Kigali: National Service of Gacaca Courts, 2012.

------. Organic Law No. 16/2004. June 19, 2004.

-----. Organic Law No. 40/2000. January 26, 2001.

-------. Organic Law No. 08/96. August 30, 1996.

--------. Organic Law No. 13/2008. May 19, 2008.

-------. Organic Law No. 31/2007. July 25, 2007.

Schabas, William A. "Genocide Trials and gacaca Courts." Journal of International Criminal Justice 3 (2005), 1-17. https://doi.org/10.1093/jicj/mqi062

Sharratt, Sara. Gender, Shame and Sexual Violence. Farnham and Burlington: ASHGATE, 2011. 
Sivakumaran, Sandesh. "Sexual Violence Against Men in Armed Conflict." European Journal of International Law 18, no. 2 (April 1, 2007), 253-276. https://doi.org/10.1093/ejil/chm013

Sumner, Maggie. “Retribution.” In The SAGE Dictionary of Criminology, edited by Eugene McLaughlin and John Muncie. London and Thousand Oaks: SAGE Publications Limited, 2013.

United Nations Secretary General. Report of the Secretary-General on the Implementation of

Security Council Resolutions 1820 (2008) and 1888 (2009). November 24, 2010, Agenda Item 33. UN Doc. A/65/592-S/2010/604.

Uwigabye, Prisca. "Gacaca and the Treatment of Sexual Offenses." In Trials and Tribulations of International Prosecution, edited by Henry F. Carey and Stacey M. Mitchell, 269-283. Lanham: Lexington Books, 2013.

Van der Merwe, Hugo. "Delivering Justice during Transition: Reserach Challenges." In Assessing the Impact of Transitional Justice: Challenges for Empirical Research, edited by Hugo Van der Merwe, Vicki Baxter and Audrey R. Chapman, 115-142. Washington, DC: United States Institute of Peace Press, 2009.

---------. "What Survivors Say about Justice: An Analysis of the TRC Victim Hearings." In Truth and Reconciliation in South Africa: Did the TRC Deliver?, edited by Audrey R. Chapman and Hugo Van der Merwe, 23-44. Philadelphia: Pennsylvania Press, 2008.

Waldorf, Lars. "Mass Justice for Mass Atrocity: Rethinking Local Justice As Transitional Justice." Temple Law Review 79, no. 1 (Spring 2006), 1-87.

--------. Transitional Justice and DDR: The Case of Rwanda. USA: International Center for Transitional Justice, June 2009. Accessed October 5, 2018. https://www.ictj.org/sites/default/files/ICTJDDR-Rwanda-CaseStudy-2009-English.pdf.

Wells, Sarah L. "Gender, Sexual Violence and Prospects for Justice at the Gacaca Courts in Rwanda." California Law Review \& Women's Studies (2005), 167-179.

Wemmers, Jo-Anne. "Victims' Need for Justice. Individual versus Collective Justice." In Victimological Approaches to International Crimes: Africa, edited by Rianne Letschert, Roelof Haveman, Anne-Marie De Brouwer and Antony Pemberton, 145-152. Cambridge, Antwerp, and Portland: Intersentia, 2011.

Wojkowska, Ewa. Doing Justice: How Informal Justice Systems can Contribute. Oslo: United Nations Development Programme, Oslo Governance Centre, 2006.

Zraly, Maggie and Laetitia Nyirazinyoye. "Don't Let the Suffering Make You Fade Away: An Ethnographic Study of Resilience among Survivors of Genocide-Rape in Southern Rwanda." Social Science \& Medicine 70, no. 10 (5/2010), 1656-1664. 